\title{
CHAPTER 121
}

\author{
Computation of Storm Surge
}

RICHARD SIIVESTER

Professor of Coastal Englneering

As1an Inst 1tute of Technology, Bangkok, Tha1land

\section{ABSTRACT}

From knowledge of wind resistance coefficients measured over the sea, it is possible to compute the shear stress of a wind field on its surface Where a body of water is relatively shallow, such a shear stress will transport water to the downwind end and so create a high water level or surge Graphs are presented for ready application of the relevant formulae to cases of lakes and Continental Shelves The wind fields of either uniform or triangular horizontal distribution in velocity are included, as well as conditions of stationary or moving fetches Surges from seven typhoons travelling towards Hong Kong are computed and compared to actual records

\section{INTRODUCTION}

Wind stress on a water surface is a function of its roughness, particularly in respect to the shorter period waves in the spectrum Hence an enclosed body of water can be hydrodynamically rougher than the open sea where the shorter waves are dissipated with the assistance of the longer ones Formulae avallable can be put in graphical form for the computation of surge helghts These apply to lakes or Continental Shelves With the latter the ratio of fetch length to Shelf width assumes importance, as well as velocity of approach of the fetch and the horizontal distribution of the wind velocity Application of the graphs to a number of typhoons approaching Hong Kong indicates the accuracy of the procedure

\section{WIND STRESS}

The shear stress applied by the wind to a water surface depends upon its smaller roughnesses and hence the wave conditions Wu(1) has shown that waves in the order of 07 seconds period and 01 metre height are the main roughness element The stress thus varies with the wind velocity and the fetch avallable For this reason it is understandable that optimum values can be reached which are different for enclosed bodies of water of limited size and the open sea The former contain a larger proportion of short waves that are reaching, or are at, their 1 imiting steepness The latter, however, when they approach the fully arisen state, contain less of the short period components and more of the longer period waves (2) For this reason the 
sea is slightly smoother as far as wind stress is concerned It can be presumed therefore that the stress of a glven steady wind can also vary with duration

The shear stress is given by

$$
\tau=\rho_{\mathrm{a}} \mathrm{U}^{2}
$$

where $\rho=$ density of alr

$\mathrm{U}^{\mathrm{a}}=$ shear velocity near the water surface

this can be expressed as

$$
\tau=\rho_{a} C_{y} U_{y}^{2}
$$

where $\mathrm{C}_{\mathrm{H}}=$ resistance coefficient varying with $\mathrm{U}$

$\mathrm{U}_{\mathrm{y}}^{\mathrm{y}}=$ wind velocity at $\mathrm{y}$ metres above water surface

Many workers $(3)(4)(5)$ have evolved relationships for $C$ and $U$ from measurements over lakes and the sea Wu $(6)$ has summarlsed the data and discussed their significance, from which Figure 1 has been prepared This shows $\mathrm{C}_{10}$ for a range of $\mathrm{U}_{10}$, as most wind measurements have been made at the 10 metre helght Within the boundary of the experimental values the relationships presented by various workers is also shown, including the stepped curve of Wu It 1 s now generally accepted that a limiting value of $C_{10}=26 \times 10^{-3}$ can be applied to limited water bodies when the 10 metre high wind exceeds 10 metres/sec or 30 knots The optimum for the ocean is $C_{10}=24 \times 10^{-3}$ For winds less than this a relationship of

$$
\mathrm{C}_{10}=065 \quad 10^{-3} \mathrm{U}_{10}^{\frac{1}{2}}
$$

would follow Sheppard's curve reasonably well to the aforesald limits To convert wind velocities from other levels to the 10 metre height, graphs have been provided elsewhere (7)

In storm surge calculations it is more appropriate to use the relationship

$$
\tau=k \rho U_{10}^{2}
$$

where $\rho=$ density of the water

so that $k=\frac{\rho a}{\rho} c_{y}$, which for seawater $=\frac{1}{800} C_{10}$

the $11 \mathrm{~m} 1 \mathrm{t}$ ing values of $\mathrm{k}=33 \times 10^{-6}$ and $30 \times 10^{-6}$ apply to 1 akes and ocean areas respectively

A scale for $k$ is included in Figure 1, together with scales for $\mathrm{U}_{10}$ in knots and designations of Beaufort Number and Sea State 


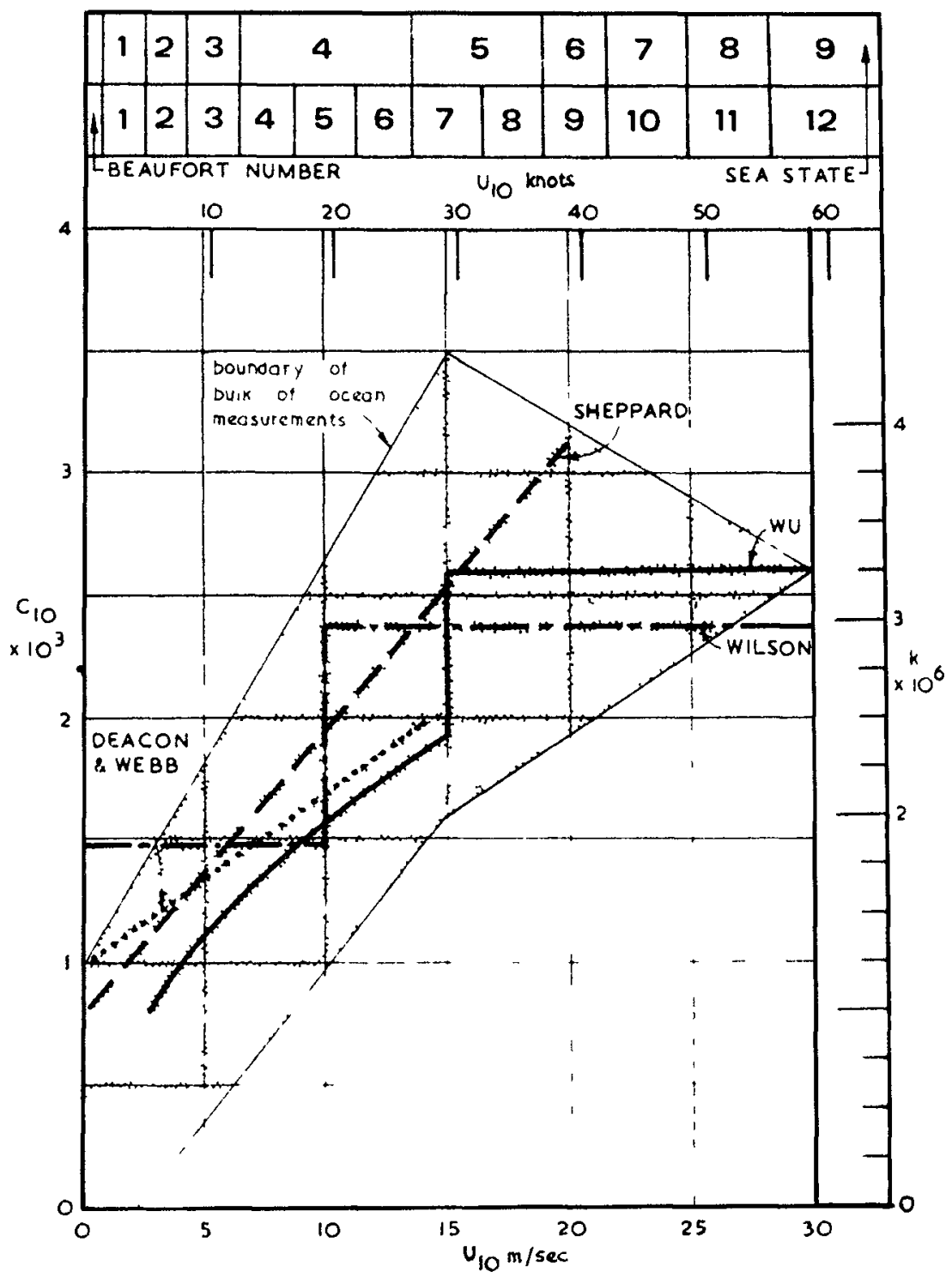

Fig 1 Variation of wind resistance coefficient with wind velocity 


\section{ENCLOSED BODIES OF WATER}

Considering a lake of rectangular proportions in plan, its longItudinal cross-section can be equated to a rectangular one of equal area, giving an equivalent depth $d$ and length or fetch $L$ The equation for the water surface profile(8)( $(9)(10)$ when a steady wind velocity $\mathrm{U}_{10}$ is applied to it is

$$
\frac{S}{d}=\frac{k_{10} U_{10^{2}}^{L}}{2 g d(d+S)}=\frac{k_{10} U_{10^{2}}^{2}}{2 g d^{2}}
$$

where $S=$ surge helght at the down wind end The last form of the equation assumes $S$ to be small in respect to d Equation (5) also approximates the nodal point at the centre of the length $L$

The variables in this dimensionless equation must be chosen consistently The values of the fall and rise of the water surface at the upwind and downwind ends of the lake are presented in graphical form in Figures 2 and 3, for the two conditions of bottom exposure at the upwind end The surface passes through the mean depth plane around the centre of the water body $(8)$ even when part of the bed is exposed Lakes of Irregular depth can be treated similarly by determining an equivalent rectangular section

In the case of narrow bodies of water such as canals the same value of $\mathrm{k}_{10}=33 \times 10^{-6}$ is applicable since the optimum roughness is due to waves of about 1 second period $(11)$ reaching their maximum steepness of $1 / 7$

For the case of non-rectangular planar shapes, of uniform depth or sloping bottoms, Keulegan (11) has derived some form factors $\mathrm{N}$ by which the values of $\mathrm{S} / \mathrm{d}$ in equation (5) should be multiplied These are Illustrated in Figure 4, where the exponential form analysed by Langhaar for constant depth $d$, and trapezoldal shapes with uniform depth or uniformly sloping bottom are presented The high values of $\mathrm{N}$ resulting from the downwind depth decreasing should be noted The same order of magnification will be observed for similar shoaling on the continental Shelf

\section{CONTINENTAL SHELF - STATIC WIND FIELD}

Where a wind is applied to the Continental Shelf blowing towards the shore, the Shelf width can be taken as half the length of the lake considered previously The water feeding the surge comes from the deep ocean The major difference from the previous situation is the decreasing depth towards the shore For the purposes of surge calculation it is reasonable to assume a uniform variation from a depth $d_{1}$ at the Shelf edge to $d_{2}$ near the coast (see inset of Figure 5)

Surge problems assume Importance on reasonably wide Continental Shelves The majority of these have been constructed by sediment deposition for which waves are the predominant distributing factor 
It is not surprising, therefore, that most of these shelf edges occur at around 65 fathoms $(12)$, or the reach of the $12-14$ second waves, which are the most persistent swe11 waves of the oceans (13) Thus, unless more specific information is avallable the depth $d_{1}$ may be taken as 400 feet (120 metres) On sandy shorelines the beach profile is parabolic from the breaker line, which produces depths of 5 fathoms very close to shore It is such depths, rather than zero values at the beach, that are more effective in the surge phenomenon Where a large tidal range occurs, or sediment of silt craracter exists, large tidal flats will necessitate the use of much smaller values of $\mathbf{d}_{2}$

The width of the Shelf will be designated as $L$, which can be different from the fetch length $F$ of the wind zone As seen in Figure 5 the depth ratio $d_{1} / d_{2}$ can be equally expressed by $L / x$ where $x$ is distance inland where the plane of the bed meets the mean water level

Where a storm zone has a fetch length (F) in excess of the Shelf width ( $\mathrm{L}$ ), only that portion across the relatively shallow zone is effective in producing surge, thus $F=L$ This is 1ikely to be the case in extra-troplcal cyclones, where wide expanses of ocean can suffer winds of unlform speed and direction In troplcal cyclones the fetch lengths are smaller and are more likely to be less than the shelf width This case is discussed later, together with the problem of velocity of advance (V) of the wind field

\section{(a) Uniform Wind Velocity $(V=0)$}

For a wind of steady and uniform speed applied to a Continental Shelf the following formula has been derived(14)

$$
S=\frac{k u^{2} L}{g\left(d_{1}-d_{2}-S\right)} \ln \left(\frac{d_{1}}{d_{2}+S}\right)
$$

Since $S$ is small compared to $d_{2}$ equation (6) can be rewritten

$$
\frac{s}{d_{1}}=\frac{k U^{2}}{g d_{1}}\left(\frac{L}{d_{1}-d_{2}}\right) \ln \frac{d_{1}}{d_{2}}
$$

so that $\frac{\mathrm{s}}{\mathrm{d}_{1}}=\frac{\mathrm{k} \mathrm{U}^{2} \mathrm{~L}}{\mathrm{gd}_{1}^{2}\left(1-\mathrm{d}_{2} / \mathrm{d}_{1}\right)} \ln \frac{\mathrm{d}_{1}}{\mathrm{~d}_{2}}$

Values of $\mathrm{S} / \mathrm{d}_{1}$ versus $\mathrm{k} \mathrm{U}^{2} \mathrm{~L} / \mathrm{gd}_{1}^{2}$ have been graphed in Figure 5 for the range of $\mathrm{L} / \mathrm{x}=\mathrm{F} / \mathrm{x}=001$ to 1000 or $\mathrm{d}_{1} / \mathrm{d}_{2}=101$ to 1001 (the latter approximating $\mathrm{d}_{2}=0$ )

\section{(b) Trlangular Wind Velocity $(V=0)$}

The wind in a tropical cyclone is circular in character, but is deflected towards the centre such that it is around $45^{\circ}$ to the radil 


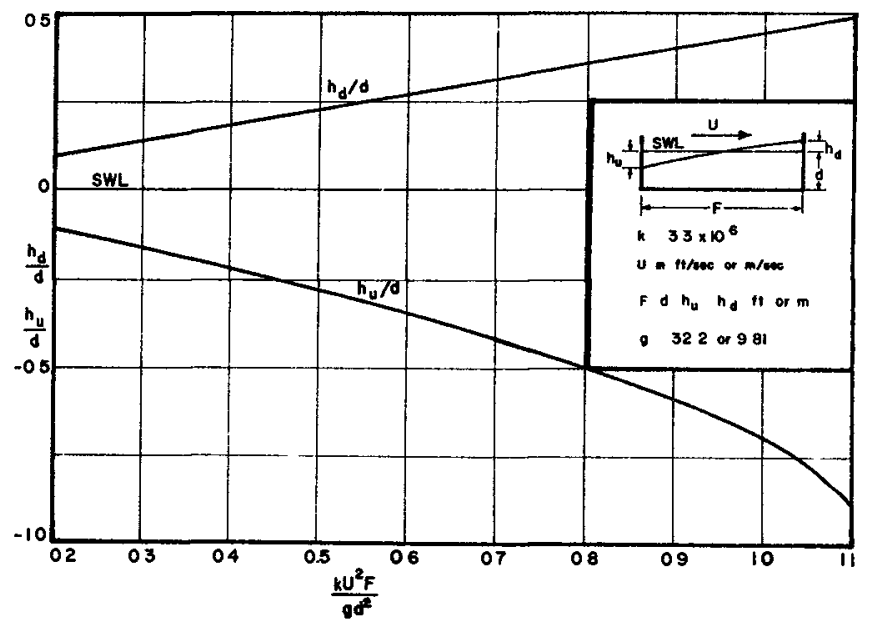

Fig 2 Upwind and downwind surge levels in a lake of uniform depth

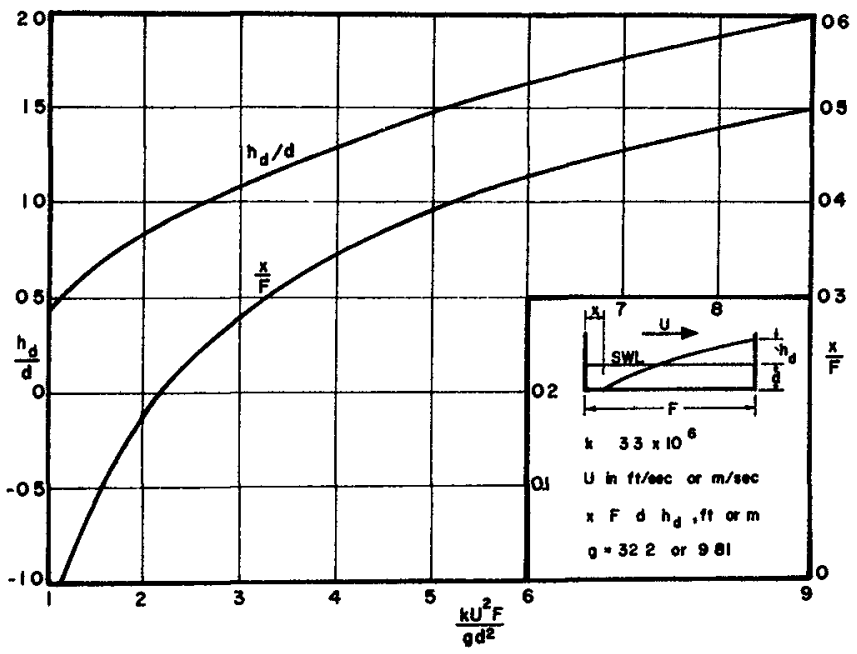

Fig 3 Surge leve1s in a lake when the upwind bed is exposed 

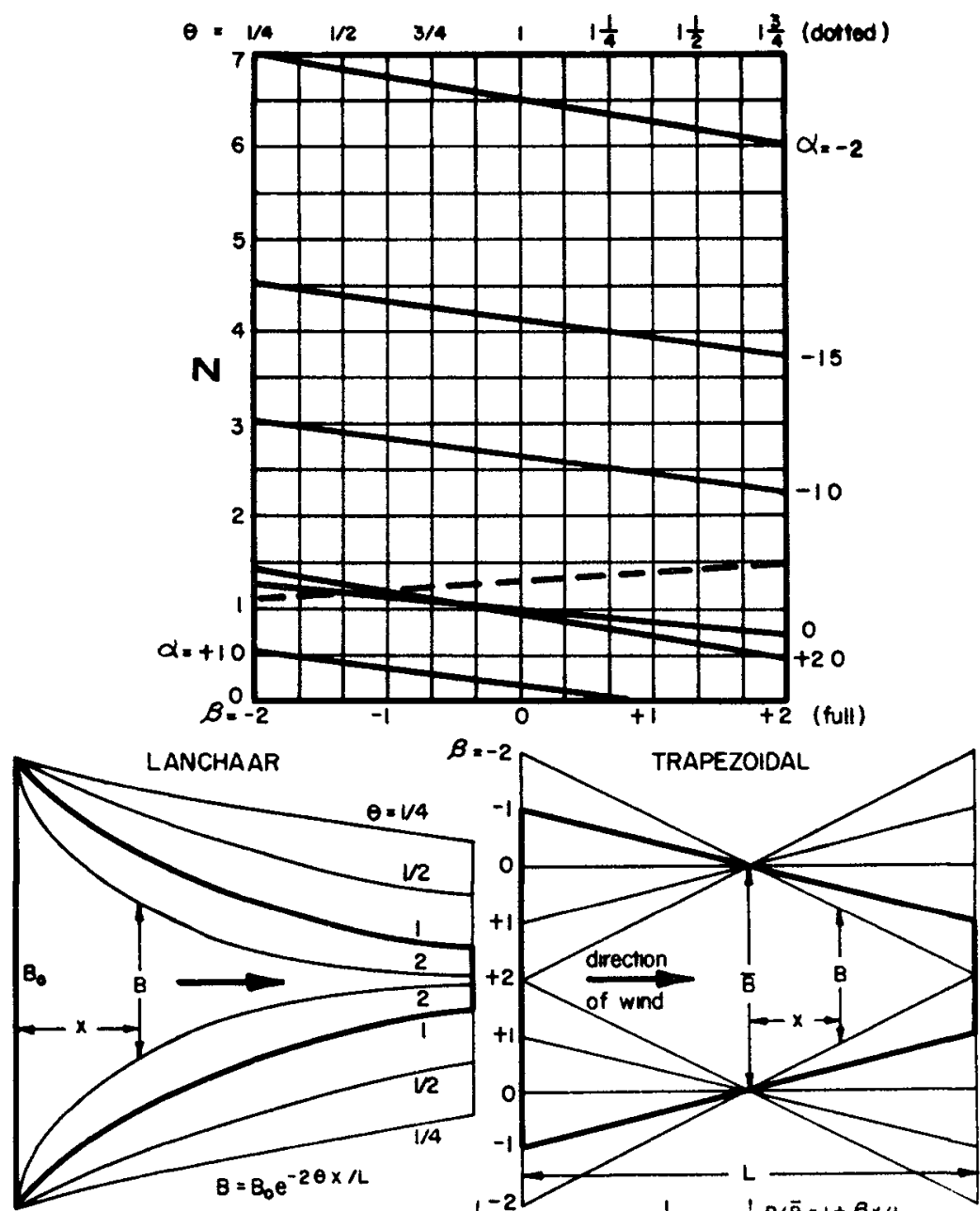
L
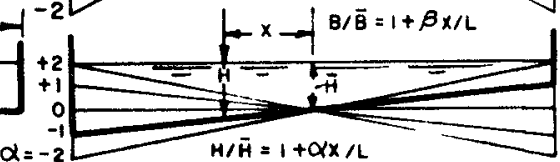

F1g 4 Amplification factor $N$ for Langhaar shaped and trapezoldal 1akes 


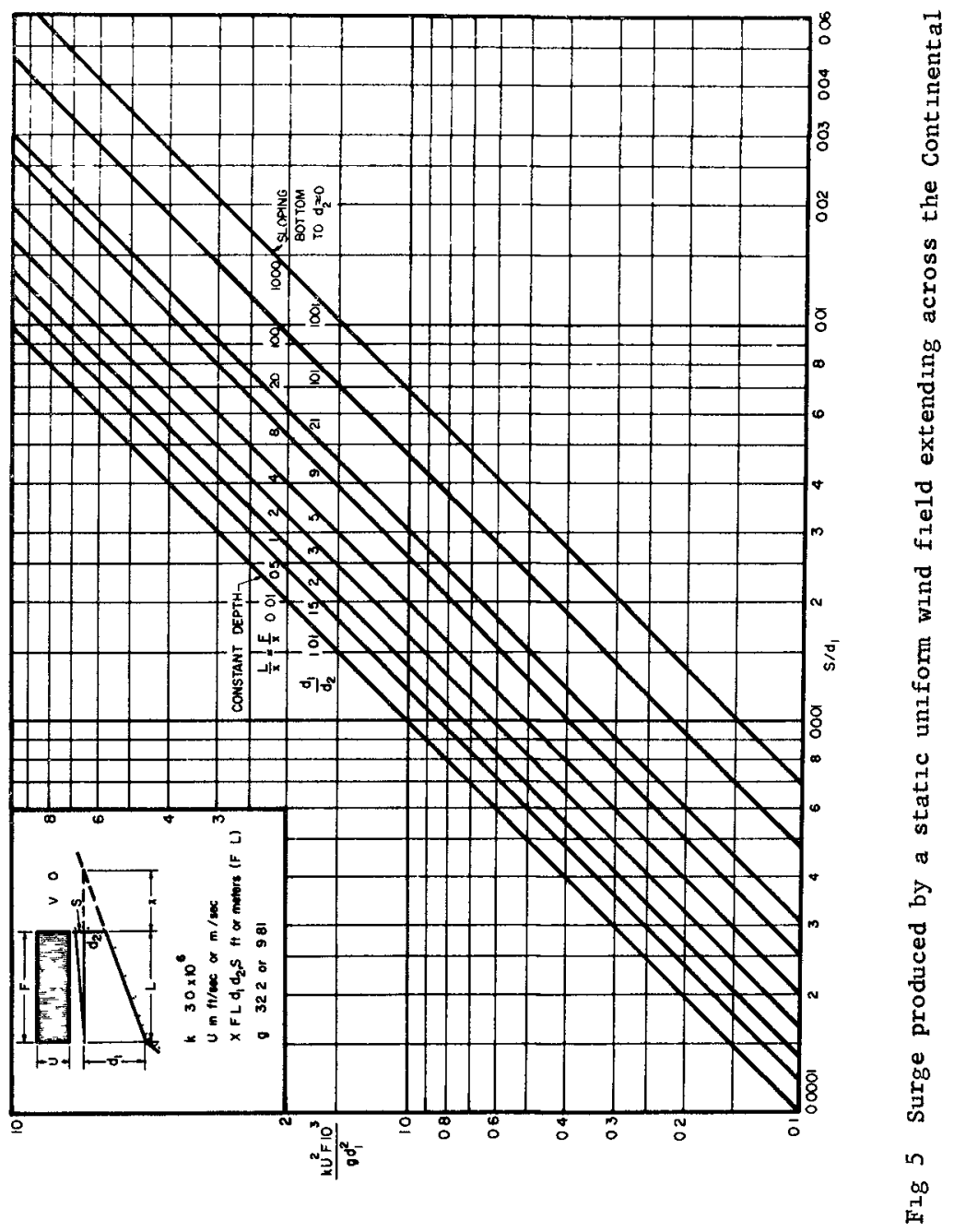




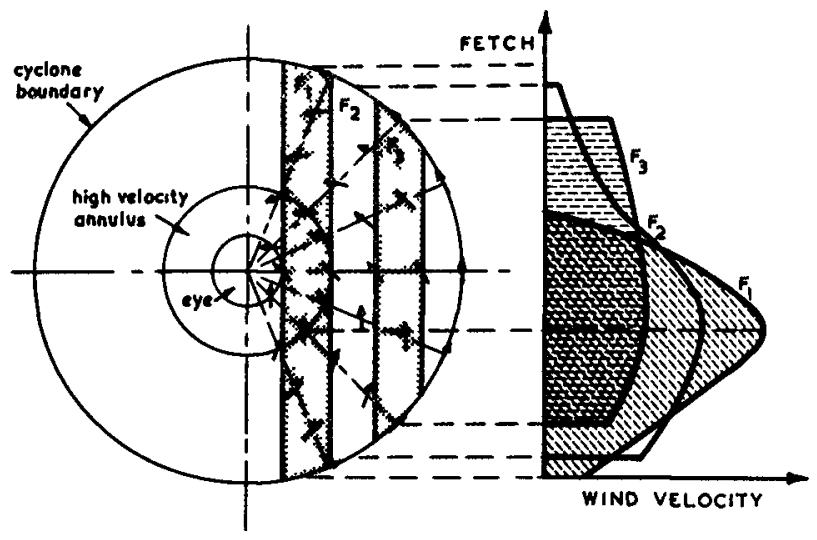

Fig 6 Typical surface wind structure inside a tropical cyclone

(See Figure 6) As the cyclonic centre moves forward the critical conditions as far as surge as well as wave generation is concerned are contained in the quadrant for which the centre and wind vectors are in same direction The cyclone depicted in Figure 6 represents alr circulation for the northern hemisphere in which the right rear quadrant contains the critical conditions for surge generation The worst affected coastal zone will be that in line with fetch $F_{1}$ passing through the high velocity annulus The assessment of wind components along this alignment will result in a triangular distribution of velocity (See Figure 6), the shape of which depends greatly on the radial distribution of the wind around the centre Reid $(15)$ a triangular wind distribution of more-or-less isosceles shape
has derived the following surge formula

$$
\mathrm{S}=\frac{\mathrm{k} \mathrm{U}^{2} \mathrm{~T}}{\mathrm{C}_{1}}\left(\frac{\mathrm{d}}{\mathrm{d}_{2}}\right)^{\frac{1}{4}} \mathrm{z}
$$

where $T=$ mean $t$ ime for surge wave to traverse the Shelf

$\begin{aligned} C_{1} & =\text { celerity of the surge wave at the Shelf edge }\left(=\sqrt{g d_{1}}\right) \\ 2 & =\text { factor, }(=056 \text { for } F=L \text { and } V=0)\end{aligned}$

Substituting $T=\frac{L}{\frac{1}{2}\left(\sqrt{g d_{1}}+\sqrt{g d_{2}}\right)}$ into equation (9) gives

$$
\frac{s}{d_{1}}=\frac{k u_{\max }^{2} L}{g d_{1}^{2}}\left[\frac{112}{1+\sqrt{d_{2} / d_{1}}}\left(\frac{d_{1}}{d_{2}}\right)^{\frac{3}{4}}\right]
$$


Equation (1) has been graphed in Figure 7 in a simılar manner to Figure 5 for a similar range of $\frac{d_{1}}{d_{2}}$ or $\frac{L}{x}+1$.

\section{CONTINENTAL SHELF - MOVING WIND FIELD}

In the case of the storm centre travelling towards the coast the initial surge wave is being reflected as later portions are still approaching The interaction of these establishes a new surge system which Reid $(15)$ has analysed for varlous ratios of $\mathrm{F} / \mathrm{L}$ and $\mathrm{V} / \overline{\mathrm{C}}$

where

$$
\vec{C}=I / T=\frac{1}{2}\left(\sqrt{g d_{1}}+\sqrt{g d_{2}}\right)
$$

From the graphs so presented the ratıo $R$ of maximun surge ( $S_{\text {max }}$ ) to that for static storm conditions ( $S$ ) ( 1 e $F=L$ and $V=0$ ) has beent plotted as in Figure 8, for both uniform and trlangular wind distributions To find $S_{\max }$ it is necessary first to compute $S$ for a hypothetical shelf whose width $L$ equals the fetch length $F$ (not the reverse) With this noted, then $R$ is obtalned from the combination of $F / L$ and $V / C$ It is seen that the influence of the storm-centre speed differs in the two wind distributions Reld's analysis(15) also provides information on the timing of the maximum surge in respect to the location of the fetch, but this has not been included

The absolute resultant is determined also by the depression of atmospheric pressure, which may precede or be concurrent with $S_{\max }$ from the wind alone The surge due to air pressure is given by

$$
\mathrm{s}_{\mathrm{a}}=\left(\frac{1013-\mathrm{p}_{\mathrm{c}}}{34}\right) \frac{1359}{121003}=\left(1013-\mathrm{p}_{\mathrm{c}}\right) 0033
$$

where $S_{2}=$ storm surge in feet of seawater and $h_{c}^{a}=$ pressure at the storm centre in millibars ( 34 millibars $=$ 1 ' mercury) This value should be added to that obtained in the previous equations

\section{EXAMPLES OF HONG KONG TYPHOONS}

Since 1962 the Department of Public Works in Hong Kong has collated some valuable data on typhoons approaching the vicinity of the island These have been summarised in a data sheet for each event, in which rainfall, wind speed, wind direction, atmospheric pressure, and sealevel are plotted against time in hours on the sealevel graph is traced the normal tide curve as preducted in tide tables, from which the surge level can be obtalned The chronologlcal relationship between the variables listed provides sufficient information to draw a plan of the cyclone and to determine its diameter A geographic plan of the ocean area with the typhoon path traced on 1t with time markings, permits the speed of travel to be assessed The distance across the Continental Shelf that the typhoon has traversed can also be measured The wind speed trace indicates whether a triangular or rectangular distribution has produced the surge A modified reproduction of one PWD data sheet is illustrated in Figure 9 


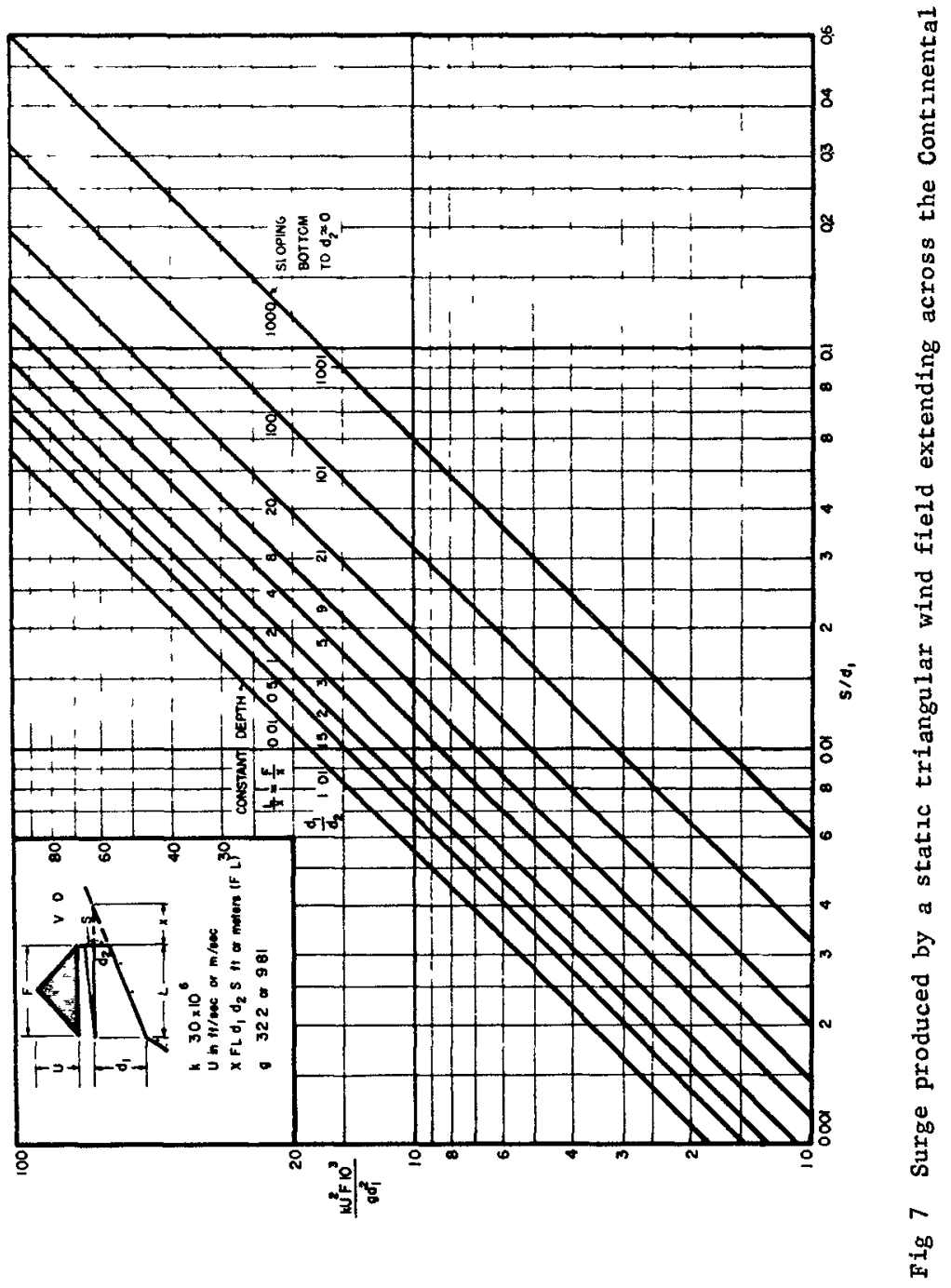




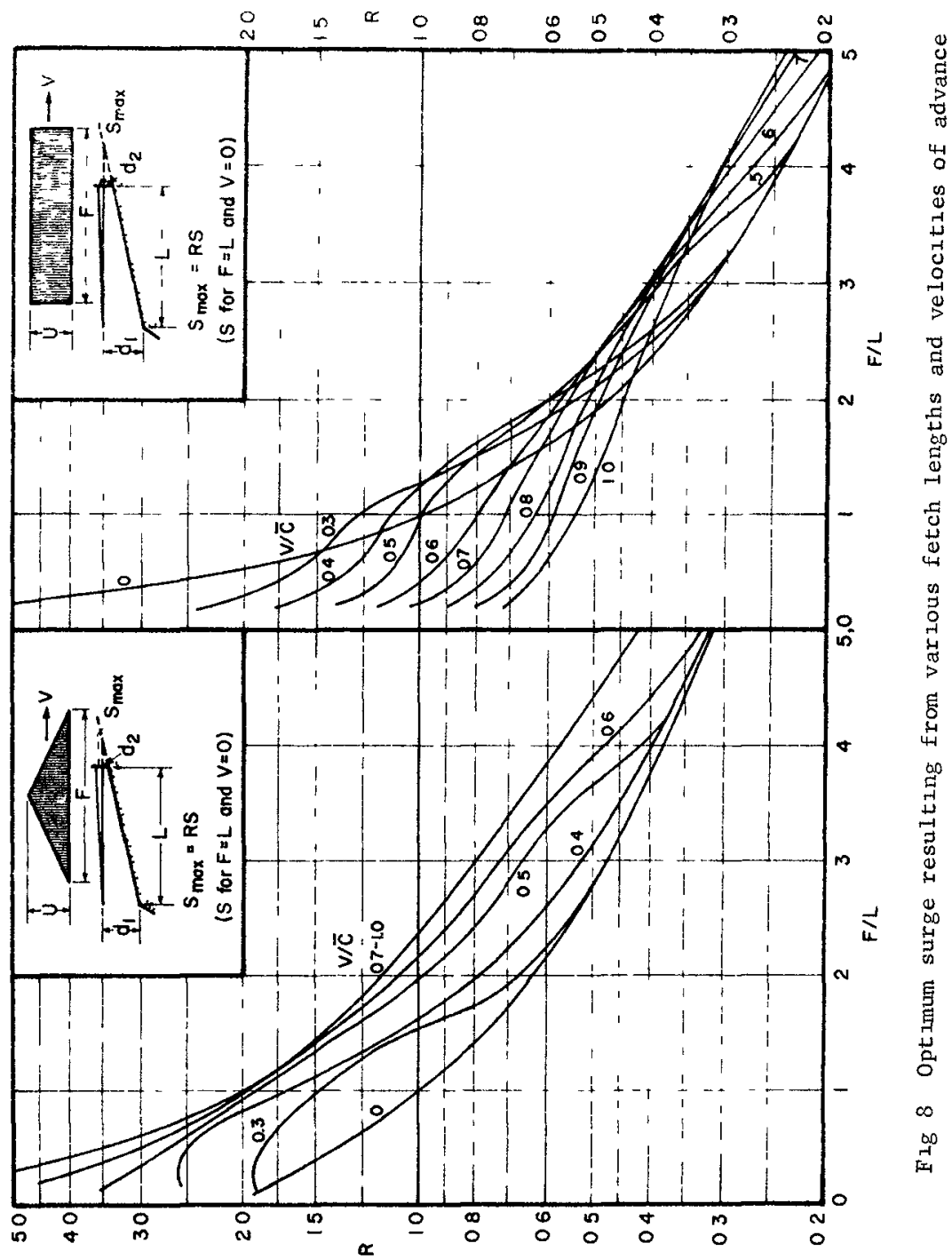




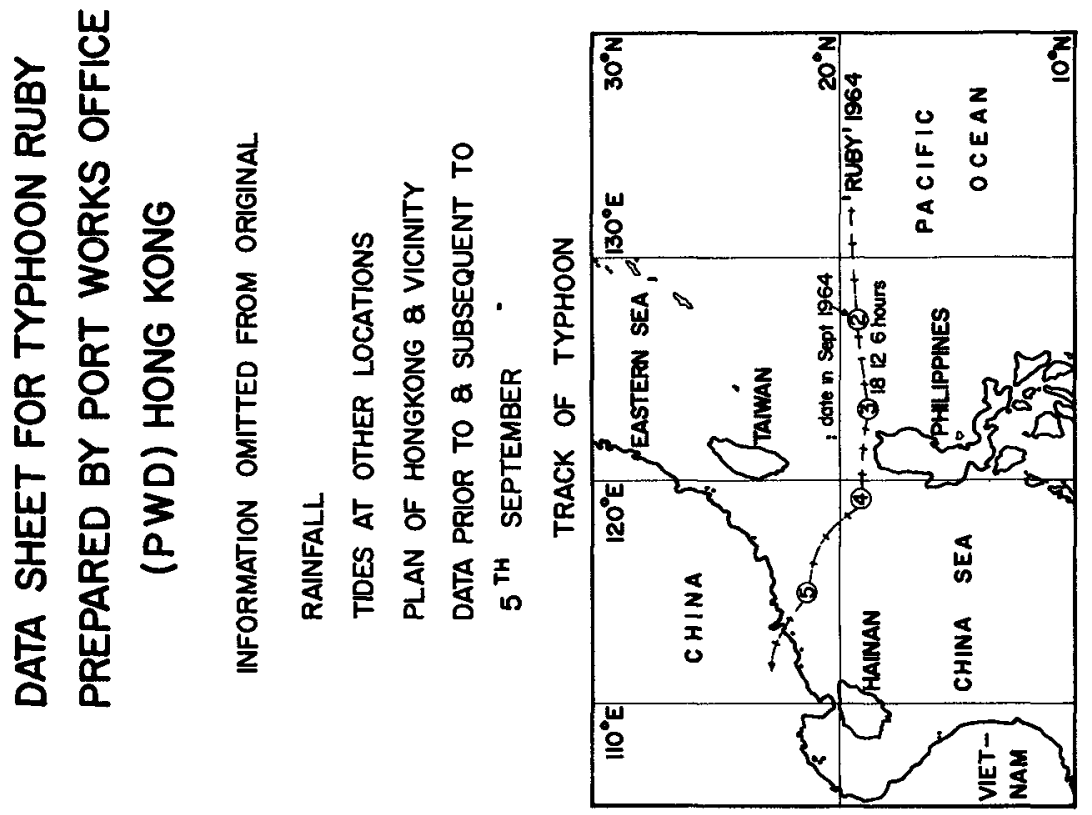

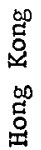

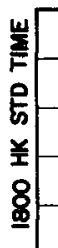
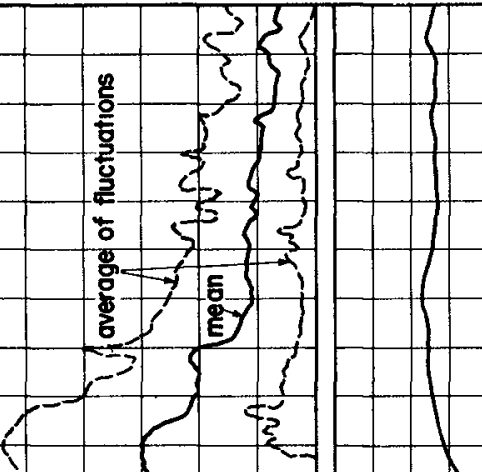

\&

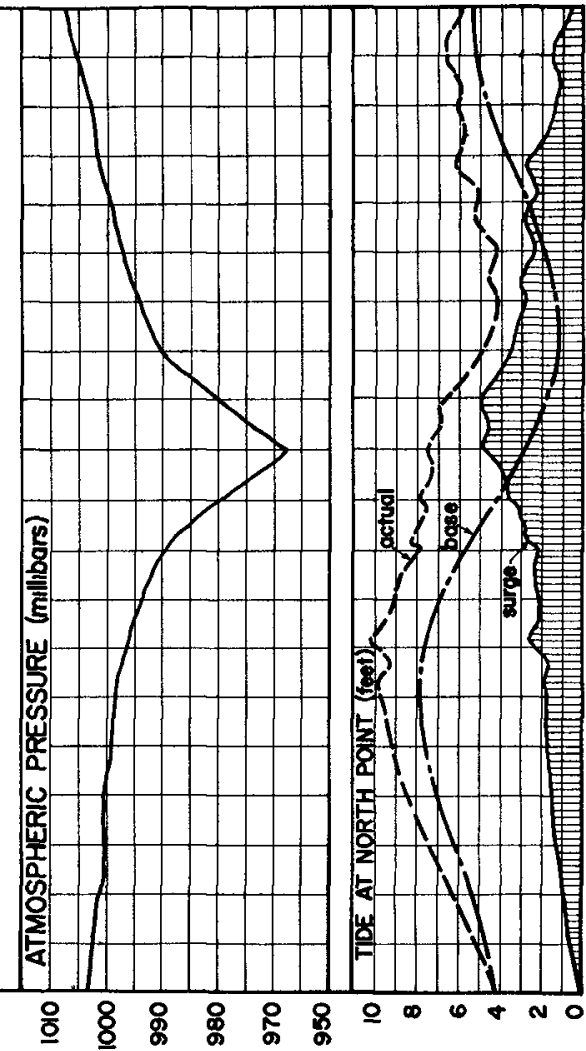


Data as above are avallable for seven typhoons, as 11sted in Table $I$, where relevant parameters leading to the final surge $\left(S_{t}\right)$ are included Comparison of the computed and measured values indicates the accuracy of the procedure presented

To determine a surge prior to 1ts arrival, the possible path in respect to the site must be assessed The maximum wind speed at the boundary of the eye is a function of the atmospheric depression at the centre Kraft $(16)$ provides an equation for Atlantic hurricanes as follows

$$
U_{\max }=14 \sqrt{1013-P_{c}}
$$

where $U_{\max }$ is expressed in knots for $p_{c}$ in millibars

Equation (13) may not be applicable to typhoons or more modest tropica1 cyclones

From table I the only typhoon which was centered on Hong Kong, and for which values could be used for verification, is that of Wanda when $U_{\text {max }}=80$ knots for $1013-952=61$ millibars This would indicate a relationship of

$$
U_{\max }=103 \sqrt{1013-\mathrm{p}_{\mathrm{c}}}
$$

The overall diameter of typhoons in the Western Pacific is around half of those normally recorded for Atlantic hurricanes It is not unreasonable, therefore, to expect lower wind velocities for any given atmospheric depression Such data should be complled for a reglon under study, when optimum storm surges are required to be calculated

The optimum water level to be expected can be computed from a knowledge of the most severe tropical cyclones known to exist in the area The fetch for this should then be traversed across the continental Shelf at the critical speed, to hit the coast just to the left (northern hemisphere) or right (southern hemisphere) of the port under study This maximum surge should then be added to MHWS level which can occur during the cyclone period of the year should the harbour be located near the head of a funnel shaped inlet, or one that has a shoaling approach channel, an amplification factor(17) may have to be determined for the surge level computed for the mouth

\section{ACKNOWLEDGEMENTS}

Appreciation is expressed to the Department of Public Works, Hong Kong, who supplied coples of their typhoon data sheets and gave permission for publication of this material 
Table I Comparison of computed and measured surges at North Point, Hong Kong harbour

\begin{tabular}{|c|c|c|c|c|c|c|c|}
\hline $\begin{array}{l}\text { Name } \\
\text { Date }\end{array}$ & $\begin{array}{l}\text { Wanda } \\
\text { Sept } 62\end{array}$ & $\begin{array}{l}\text { Faye } \\
\text { Sept } 63\end{array}$ & $\mid \begin{array}{l}\text { Viola } \\
\text { May 64 }\end{array}$ & \begin{tabular}{|ll} 
Idal & \\
Aug & 64
\end{tabular} & $\begin{array}{l}\text { Ruby } \\
\text { Sept } 64\end{array}$ & $\begin{array}{l}\text { Sally } \\
\text { Sept } 64\end{array}$ & $\begin{array}{l}\text { Shirley } \\
\text { Aug } 68\end{array}$ \\
\hline $\begin{array}{l}\Delta p(m b) \\
s_{a}(\text { feet })\end{array}$ & $\begin{array}{rl}61 & \\
2 & 02\end{array}$ & $\begin{array}{l}17 \\
057\end{array}$ & \begin{tabular}{rr|r|}
21 & \\
0 & 70
\end{tabular} & $\begin{array}{rr}38 & \\
1 & 27\end{array} \mid$ & $\begin{array}{r}45 \\
150\end{array}$ & $\begin{array}{r}24 \\
080\end{array}$ & $\begin{array}{l}44 \\
147\end{array}$ \\
\hline $\begin{array}{l}U_{\max } \text { (knots) } \\
\text { D1stribution } \\
F \text { (NM's) }\end{array}$ & $\begin{array}{r}80 \\
\Delta \\
55\end{array}$ & $\int_{220}^{25}$ & $\int_{110}^{30}$ & $\begin{array}{r}45 \\
\Delta \\
210\end{array}$ & $\begin{array}{r}60 \\
\Delta \\
166\end{array}$ & $\begin{array}{r}35 \\
\Delta \\
107\end{array}$ & $\begin{array}{r}42 \\
\Delta \\
90\end{array}$ \\
\hline 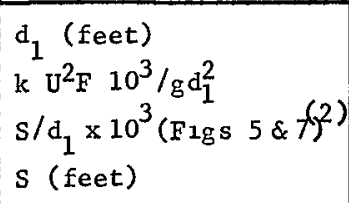 & |r $\begin{array}{rl}400 & \\
3 & 55 \\
5 & 5 \\
2 & 2\end{array}$ & $\begin{array}{rl}400 & \\
1 & 4 \\
3 & 8 \\
1 & 52\end{array}$ & $\left|\begin{array}{rl}400 & \\
1 & 0 \\
2 & 7 \\
1 & 08\end{array}\right|$ & $\mid \begin{array}{rr}400 & \\
4 & 3 \\
6 & 5 \\
2 & 6\end{array}$ & $\begin{array}{rl}270^{(1)} \\
13 & 7 \\
20 & 0 \\
5 & 4\end{array}$ & $\mid \begin{array}{rl}400 & \\
1 & 32 \\
2 & 0 \\
0 & 8\end{array}$ & $\mid \begin{array}{rr}400 & \\
1 & 6 \\
2 & 5 \\
1 & 0\end{array}$ \\
\hline $\begin{array}{l}\mathrm{L} \text { (NM's) } \\
F / L \\
V(\text { knots }) \\
V / \vec{C} \\
R(F 1 g 8) \\
S_{\max }(=R S)\end{array}$ & $\begin{array}{rl}180^{(3)} & \\
0 & 3 \\
12 & \\
0 & 280 \\
1 & 9 \\
4 & 18\end{array}$ & \begin{tabular}{|cl}
240 & $(4)$ \\
0 & 92 \\
10 & \\
0 & 234 \\
1 & 3 \\
1 & 98
\end{tabular} & $\left|\begin{array}{cl}120 & \\
0 & 92 \\
8 & \\
0 & 187 \\
1 & 4 \\
1 & 51\end{array}\right|$ & $\mid \begin{array}{rl}120 \\
1.75 \\
15 \\
0 & 350 \\
0 & 9 \\
2 & 34\end{array}$ & \begin{tabular}{|cl}
$80^{(1)}$ \\
2 & 08 \\
12 & 8 \\
0 & 348 \\
0 & 7 \\
3 & 78
\end{tabular} & $\begin{array}{rl}120 & \\
0 & 89 \\
13 & 3 \\
0 & 312 \\
1 & 6 \\
1 & 28\end{array}$ & $\begin{array}{rl}120 & \\
0 & 75 \\
9 & 1 \\
0 & 213 \\
1 & 5 \\
1 & 5\end{array}$ \\
\hline $\begin{array}{l}s_{t}\left(=s_{a}+s_{\max }\right) \\
s \text { (measured) }\end{array}$ & $\begin{array}{ll}6 & 20 \\
4 & 6\end{array}$ & $\begin{array}{ll}2 & 55 \\
2 & 8\end{array}$ & $\begin{array}{ll}2 & 21 \\
3 & 0\end{array}$ & $\begin{array}{ll}3 & 61 \\
4 & 0\end{array}$ & $\begin{array}{ll}5 & 28 \\
5 & 0\end{array}$ & $\begin{array}{ll}2 & 08 \\
1 & 8\end{array}$ & $\begin{array}{ll}2 & 97 \\
3 & 0\end{array}$ \\
\hline
\end{tabular}

(1) Typhoon changed direction part way across Shelf where $d_{1}=270$ feet and $\mathrm{L}=80 \mathrm{NM}^{\prime} \mathrm{s}$

(2) Assuming $d_{2}=30$ feet

(3) Approach was from ESE, equivalent $I=180 \mathrm{NM}$ 's

(4) Approach was from east, equivalent $L=240 \mathrm{NM}^{\prime} \mathrm{s}$

(5) Tide gauge out, water mark observations only 


\section{REFERENCES}

(1) Wu J "A criterion for determining alr-flow separation from wind waves", Tellus 21, 1969, 707-714

(2) Barnett T P and A J Sutherland "A note on an overshod effect In wind generated waves" J Geoph Res, 1968, 6879-6885

(3) Sheppard P A "Transfer across the earth's surface and through the alr above", Quart J Roy Met Soc , 84, 1958, 205-224

(4) Deacon E L and E K Webb "Sma11 scale interaction" The Sea (Ed M N H111) Interscience $\mathbb{N} \times 1062$

(5) W11son B W "Note on surface wind stress over water at low and hıgh w1nd speeds", J Geoph Res 65, 1960, 3377-3382

(6) Wu $\mathrm{J}$ "Wind stress and surface roughness at sea interface" J Geoph Res 74, 1969, 444-455

(7) Silvester $R$ and $S$ Vongvisessomja1 "Energy distribution curves of developing and fully arısen seas" J Hyd Res (In Press)

(8) He1lstrom B "Wind effect on 1akes and rivers" Roy Inst of Tech Stockholm, Bul1 41, 1941

(9) Langhaar H L "Wind t1des in inland waters" Proc M1d Western Conf on Flu1d Mechs , 1951, p 278

(10) Keulegan G H "Wind tides in small closed channels" $J$ Res of Nat Bur Stds, 46,1951

(11) Keulegan GH "The form factor in wind-t1de formulas", Nat Bur Stds Rep No 1835,1952

(12) Shepard F D Submarine Geology (2nd Ed ) Harper \& Row N Y , 1963

(13) Silvester $\mathrm{R}$ and $\mathrm{S}$ Vongvisessomja1 "Computation of Storm Waves and Swel1" Proc I.C E (In Press)

(14) Bretschneıder C L "Englneerıng aspects of hurricane surge" Estuary and Coast11ne Hydrodynamics (Ed A T Ippen), McGraw-H111, 1966, 231-256

(15) Reid R O "Approximate response of water level on a sloping shelf to a wind fetch whlch moves towards shore" Beach Erosion Board, Tech Mem No 83, 1956

(16) Kraft $\mathrm{R} \mathrm{H}$ "The hurricane's central pressure and h1ghest winds" Mar1ners Weather Log $\underline{5}(5), 1961$

(17) Silvester $R$ "Tides and long period waves on continental margins" Proc 13th Congress I A H R , 3, 1969, 113-121 